\title{
Investigating on-line pornography at the University of Johannesburg
}

\author{
P. Laughton \\ Centre for Information and Knowledge Management \\ University of Johannesburg \\ Johannesburg, South Africa \\ paull@uj.ac.za \\ C. Rensleigh \\ Centre for Information and Knowledge Management \\ University of Johannesburg \\ Johannesburg, South Africa \\ crensleigh@uj.ac.za
}

The on-line user of today has access to a vast collection of information resources. In addition, the developments in Internet and Web technologies have made it even easier for surfers to anonymously get access to on-line pornography. The purpose of this research was to investigate the extent to which access to on-line pornography at the University of Johannesburg can be managed. For the empirical part of this research 1037 questionnaires were proportionally distributed to and completed by students on all five campuses of the university. The questionnaire consisted of four sections: biographical information; university computer facility usage; university acceptable use policy; and personal experience with university computer facilities. The gender distribution for the sample was almost even, with a total of 49,4\% male participants and 50,6\% female, with the largest grouping of respondents (61,6\%) aged between 19 years and 21 years. Of the respondents, 36,7\% indicated that exposure to unsolicited pornography did not bother them. When asked to what extent students should have access to pornography, 60,5\% stated 'None' while 32,6\% believed that 'Restricted' access should be granted for research purposes and 6,9\% believed that students should be granted 'Total' access to pornography. Results from the research will be used to manage access to on-line resources at the University of Johannesburg better.

Key words: On-line pornography, higher education, content filtering

\section{Contents}

1. Introduction

2. Rationale of the research

3. Defining pornography

3.1 Defining illegal pornography

4. Empirical research

4.1 Data collection and data processing procedures

4.2 Statistical analysis of questionnaires 
5. Interpretation of results from questionnaires

5.1 Biographic information

5.2 University computer facility usage

5.3 University AUP

5.4 Personal experience with the university's computer facilities

6. Conclusion

7. References

\section{Introduction}

Pornography in Western universities is commonplace, especially in North America where student newspapers and magazines dealing with sexual expression and sexuality can be found. Two examples are the Boink Magazine at Boston University and the H-Bomb at Harvard University (Chheuy 2004). Some US universities, such as New York University, UMass Amherst, Penn State, Vanderbilt, North Western, San Francisco State, UCLA, UC Berkley, UC Santa Barbra and Arizona State University, offer pornography courses as a possible career opportunity (Cullen 2006). This article reports on an investigation with regard to on-line pornography at the University of Johannesburg (UJ), South Africa. The following research question was formulated for this research:

To what extent can access to on-line pornography be managed within a university, with special reference to the University of Johannesburg?

\section{Rationale of the research}

The underlying purpose of the research was to test the effectiveness of current on-line content filters and acceptable use policies (AUPs) at UJ. In addition, the students' opinion was polled regarding their view on content that they would like to have access to. From the research data gathered, recommendations can be made for the creation of a comprehensive approach to managing access to pornography in an on-line environment. This approach should ideally consist of two components, an active and passive approach. The active approach typically consists of a mechanism (e.g. content-filtering solution) that physically restricts users from viewing content outlined as unacceptable. The passive approach cannot physically restrict users from viewing unacceptable content but, in the form of a policy, it may condemn such behaviour.

\section{Defining pornography}

Today the word pornography or porn is commonly used. What was once a taboo subject has become a common occurrence in society through various media. There is, however, a lack of clarity about the definitions and terms associated with pornography. The definition of pornography is determined by a society's norms and values, as well as its perspectives, whether they are conservative, liberal, post-modern or feminist. These factors are used when deciding what content is of a pornographic nature. At the same time, there are a host of other words associated with pornography, such as erotica, obscenity and indecency, that fall in the same grey area (Halavais 2005). The word pornography originates from the term pornogrophs, which were ancient Greek writings of encounters with prostitutes (Rothery 2003). The word has been adapted and is used to describe more than just writings about 
prostitutes. This definition and medium for delivery has evolved somewhat to be used in the modern context.

The Concise Oxford English Dictionary (2004) defines pornography as printed or visual material intended to stimulate sexual excitement. The Merriam Webster Dictionary of Law (1996) defines pornography as material that depicts erotic behaviour and is intended to cause sexual excitement. Both these definitions refer to the term erotic, which is seen as an artistic and more acceptable form of pornography.

Erotica, a word closely associated with pornography, explores the artistic nature of pornography. The word originates from a Greek word, eros, meaning love. This includes works of art such as literature, photographs, films, sculpture and paintings that deal with arousing content. In modern times, erotica is used to describe the portrayal of human sensuality and sexuality with artistic aspirations. While pornography tends to focus on unemotional lust, erotica defines material with higher emotional involvement. Soft pornography is a similar type of commercial art that lies between erotica and hardcore pornography (Wikipedia 2005).

\subsection{Defining illegal pornography}

When referring to the legal definitions of pornography, one identifies content of an obscene nature, which is deemed illegal by society and Western law. These definitions vary slightly on different legal constitutions. Two defining court cases have been used internationally as a benchmark to form a definition of illegal pornography (obscenity), namelyRoth vs. United States in 1957 and Miller vs. California in 1973.

The South African constitution addresses the issue of illegal pornography through the Films and Publications Act. This act identifies three categories of pornography, separating acceptable pornography from illegal and obscene content (Watney 2005):

Category 1: XX classification of content is subject to the form of communication, publication or film consisting of:

- Bestiality, incest and rape

- Explicit sexual conduct that violates or shows disrespect for the right to human dignity or degrades a person, which constitutes incitement to cause harm

- Explicit infliction of or explicit effect of extreme violence, which constitutes incitement or cause of harm.

It is illegal to possess or distribute anything in this category in South Africa (Watney 2005).

Category 2: X18 classification of content. Explicit sexual conduct, simulated or real, which in the case of sexual intercourse includes explicit visual presentation of genitals. It is not illegal to possess or distribute this form of pornography to those over the age of 18 .

Category 3: This category classifies child pornography. This includes any image, however created, or description of a person, real or simulated, who is depicted or described as under the age of 18 who is:

- Engaged in sexual conduct

- Participating or assisting another to participate in sexual conduct

- Showing or describing the body or any part of the body in a manner which amounts to sexual exploitation.

This category of content is illegal in South Africa and people charged with regard to material 
of this category suffer harsh prison sentences.

Contrary to popular belief, not all forms of pornography are illegal. Only content that is deemed obscene is illegal, as is any other pornographic content in the hands of people under the age of 18 years. One very disturbing form of pornography is that of child pornography. This content has become more popular with the advancement in technology (e.g. Internet and the Web), allowing people to distribute and search for content of such nature anonymously with little chance of being traced. For the purpose of this research, a pornography taxonomy was compiled (Figure 1).

Figure 1 Taxonomy of pornography (Laughton and Rensleigh 2007)

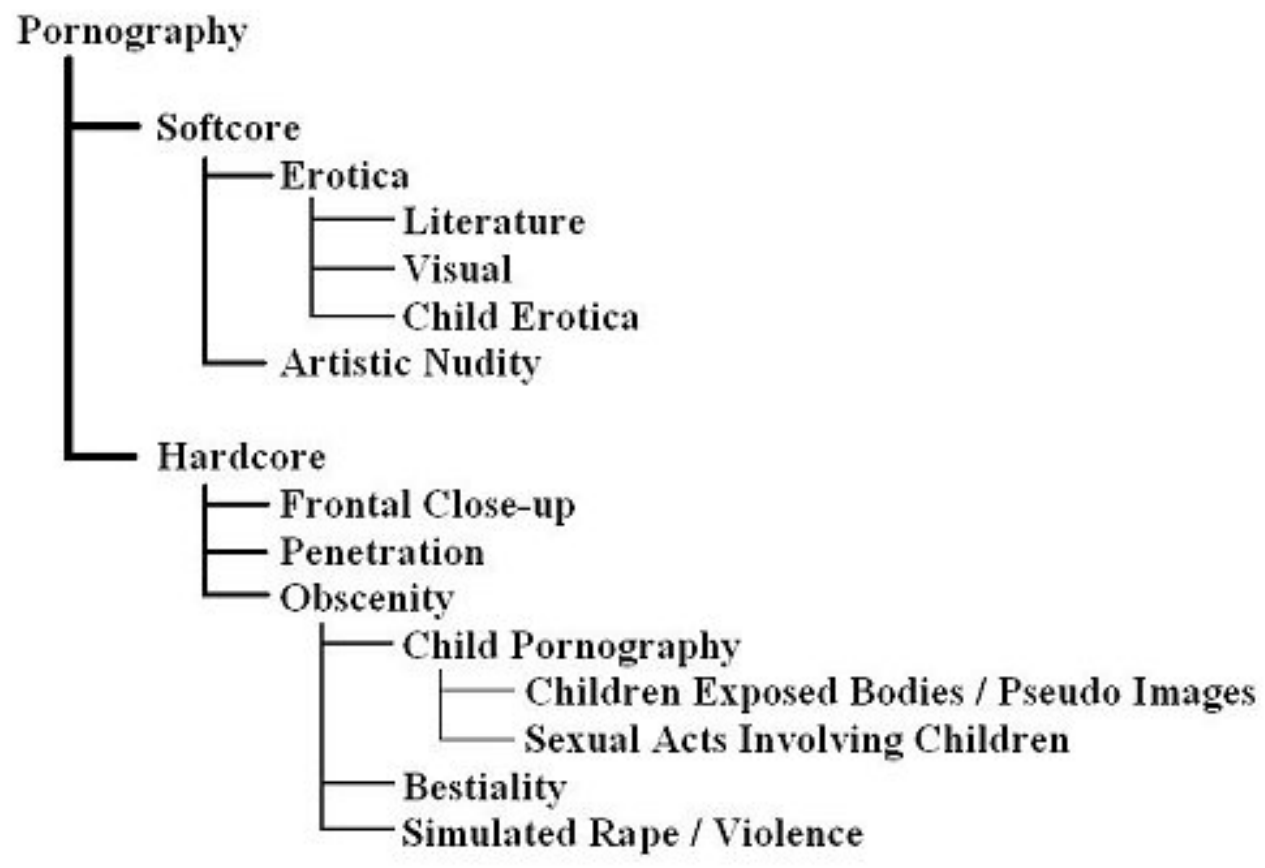

The main categories identified in the taxonomy are softcore and hardcore. From these two main categories, pornography is dissected into sub-sections. From the 10 categories identified, only the following four are illegal in terms of the South African law system:

- Children's exposed bodies/pseudo images

- Sexual acts involving children

- Bestiality

- Simulated rape/violence.

\section{Empirical research}

A quantitative research approach in the form of a survey was adopted and the sample group was selected from the UJ. The UJ is a newly formed university comprising of three previous institutions: Rand Afrikaans University, Technikon Witwatersrand and Vista University's Soweto and East Rand campuses. To ensure equal representation from the five UJ campuses (Bunting Rd, Doornfontein, East Rand, Kingsway and Soweto) a sample group of 1000 students was divided into the different campuses using the number of registered students at each campus as an indicator to obtain proportional representation. Each campus's target was calculated as a percentage of the total number of registered students. Table 1 shows the breakdown of registered students per campus as well as the distribution of the sample over 
the different campuses.

Table 1 Sample distribution among the different campuses

\begin{tabular}{|l|c|c|c|}
\hline UJ campus & $\begin{array}{c}\text { Number of } \\
\text { registered } \\
\text { students }\end{array}$ & \% of the total & $\begin{array}{c}\text { Minimum size } \\
\text { of sample }\end{array}$ \\
\hline Bunting Rd & 7943 & 15,86 & 160 \\
\hline Doornfontein & 9549 & 19,06 & 190 \\
\hline East Rand & 455 & 0,9 & 10 \\
\hline Kingsway & 30703 & 61,3 & 610 \\
\hline Soweto & 1443 & 2,88 & 30 \\
\hline Total & $\mathbf{5 0 0 9 3}$ & $\mathbf{1 0 0}$ & $\mathbf{1 0 0 0}$ \\
\hline
\end{tabular}

\subsection{Data collection and data processing procedures}

A questionnaire was used to gather insight into the effectiveness of current content filtering practices and to gain knowledge as to what content students feel they should be granted access to. To ensure the continuity and consistency of questions, the questionnaire was designed in conjunction with Statcon (UJ Statistical Consulting Service) on the Kingsway campus. The questionnaire consisted of four sections:

- Section A: Biographic information

- Section B: University computer facility usage

- Section C: University AUP

- Section D: Personal experience with university computer facility.

All except one question were closed-ended where the respondents were required to select the most appropriate alternative. Questionnaires were handed out to students at the different campuses at the computer laboratories. At Bunting Rd, East Rand and Soweto campus the computer laboratories were located within the libraries. At Doornfontein, a separate venue is dedicated to computer facilities while, at Kingsway, various venues, including the library, are allocated to computer laboratories. Student assistants from the Department of Information and Knowledge Management handed out questionnaires and were overseen by the researcher. The average completion time for the questionnaire was approximately 10 minutes. This phase of the research took 14 days to complete.

Once all the completed questionnaires had been collected, they were sent to Statcon for processing and analysis. The initial frequencies were made available within three weeks. Further consultations with Statcon followed to finalize cross tabulation for a more in-depth statistical analysis.

\subsection{Statistical analysis of questionnaires}

Frequency analysis and interpretation of responses to the questionnaires were used to identify common trends while cross table comparisons were used to give further insight into possible relationships between questionnaire variables. The interdependencies of these variables were statistically analysed using a form of hypothesis testing.

Effect size is used to determine the nature of a relationship between two variables. When determining the effect size (using Cramer's V and Phi coefficient method) the test sample 
size is not an inhibiting factor, as the bigger the test sample, the stronger the power of the test. Rosenthal, Rosnow and Rubin (2000:15) identify four groups of effects: no effect, small effect, medium effect and large effect, as seen in Table 2.

Table 2 Rosenthal's description of effect sizes (Rosenthal et al. 2000:15)

\begin{tabular}{|l|c|}
\hline \multicolumn{1}{|c|}{ Description } & Effect size \\
\hline No effect & $0,0-0,1$ \\
\hline Small effect & $0,1-0,3$ \\
\hline Medium effect & $0,3-0,5$ \\
\hline Large effect & $0,5-1$ \\
\hline
\end{tabular}

A small effect size means there is no or very little dependency between the two variables. A large effect size shows a significant or great dependency between the two identified variables.

In Question 8 of the survey, students were asked how often they surfed the Web at the UJ. This question was useful to establish if either males or females were more susceptible to exposure to on-line pornography relative to the time spent on the Web. Table 3 indicates that a larger percentage of males were using the Web more frequently. Statistical analysis was done to identify the effect size.

Table 3 Cross tabulation of gender difference for Question 8 (surfing the Web at the UJ)

\begin{tabular}{|c|c|c|c|c|c|c|c|c|}
\hline & & & \multicolumn{6}{|c|}{ Frequency of surfing the Web at the UJ } \\
\hline & & & $\begin{array}{c}\text { At least } \\
\text { every } \\
\text { day }\end{array}$ & $\begin{array}{c}\text { Twice a } \\
\text { week }\end{array}$ & $\begin{array}{c}\text { Once a } \\
\text { week }\end{array}$ & $\begin{array}{l}\text { Once a } \\
\text { month }\end{array}$ & \begin{tabular}{|l|} 
I only \\
surf the \\
Internet \\
at home
\end{tabular} & Total \\
\hline \multirow{4}{*}{ Gender } & \multirow[b]{2}{*}{ Male } & Count & 181 & 164 & 90 & 47 & 18 & 500 \\
\hline & & $\begin{array}{l}\% \\
\text { within } \\
\text { gender }\end{array}$ & $36,2 \%$ & $32,8 \%$ & $18 \%$ & $9,4 \%$ & $3,6 \%$ & $100 \%$ \\
\hline & \multirow[b]{2}{*}{ Female } & Count & 137 & 153 & 117 & 74 & 33 & 514 \\
\hline & & $\begin{array}{l}\% \\
\text { within } \\
\text { gender }\end{array}$ & $26,7 \%$ & $29,8 \%$ & $22,8 \%$ & $14,4 \%$ & $6,4 \%$ & $100 \%$ \\
\hline \multirow{2}{*}{\multicolumn{2}{|c|}{ Total }} & Count & 318 & 317 & 207 & 121 & 51 & 1014 \\
\hline & & $\begin{array}{l}\% \\
\text { within } \\
\text { gender }\end{array}$ & $31,4 \%$ & $31,3 \%$ & $20,4 \%$ & $11,9 \%$ & $5 \%$ & $100 \%$ \\
\hline
\end{tabular}

\begin{tabular}{|l|l|l|l|}
\hline & Value & df & Asymp. sig. (2-sided) \\
\hline Pearson chi-square & $20,239^{\mathrm{a}}$ & 4 & 0,000 \\
\hline Likelihood ratio & 20,381 & 4 & 0,000 \\
\hline Linear-by-linear association & 19,850 & 1 & 0,000 \\
\hline
\end{tabular}




\begin{tabular}{|l|l|l|l|}
$\mathbf{N}$ of valid cases & 1014 & & \\
\hline & & & \\
\hline $\begin{array}{l}\mathrm{a} 0 \text { cells }(0,0 \%) \text { have expected count less than } 5 \text {. The minimum expected count is } \\
25,15\end{array}$ \\
\hline
\end{tabular}

\begin{tabular}{|l|l|l|l|}
\hline & & Value & Approx. sig. \\
\hline Nominal by & \multicolumn{1}{|c|}{$\boldsymbol{P h i}$} & 0,141 & 0,000 \\
\hline Nominal & Cramer's $\boldsymbol{V}$ & 0,141 & 0,000 \\
\hline N of valid cases & & 1014 & \\
\hline & & & \\
\hline \multicolumn{3}{|l}{ - Not assuming the null hypothesis } \\
- Using the asymptotic standard error assuming the null hypothesis
\end{tabular}

A small effect size was achieved, indicating a relative magnitude of difference between male and female respondents. The proportion of males who surf the Web at least every day differs significantly from the proportion of females who surf the Web at least every day and, therefore, males are at a higher risk of being exposed to pornography. In Question 12 of the survey, students were asked how tolerant they regard themselves towards exposure to unsolicited pornography at the UJ. In Table 4 it is indicated that a larger percentage of males were not bothered by this exposure, as opposed to the female respondents. Statistical analysis was done to determine the effect size.

Table 4 Cross tabulation of gender differences for Question 12 (exposure to unsolicited pornography at the UJ)

\begin{tabular}{|c|c|c|c|c|c|c|c|}
\hline & \multicolumn{5}{|c|}{ Exposure to unsolicited pornography at the UJ } \\
\hline & & & $\begin{array}{c}\text { Does } \\
\text { not } \\
\text { bother } \\
\text { me }\end{array}$ & $\begin{array}{c}\text { Bothers } \\
\text { me }\end{array}$ & \begin{tabular}{|c|} 
Deemed as \\
unacceptable
\end{tabular} & $\begin{array}{l}\text { Students } \\
\text { should have } \\
\text { the freedom } \\
\text { to access } \\
\text { pornography }\end{array}$ & Total \\
\hline \multirow{4}{*}{ Gender } & \multirow[b]{2}{*}{ Male } & Count & 214 & 111 & 127 & 45 & 497 \\
\hline & & $\begin{array}{l}\% \\
\text { within } \\
\text { gender }\end{array}$ & $43,1 \%$ & $22,3 \%$ & $25,6 \%$ & $9,1 \%$ & $100 \%$ \\
\hline & \multirow[b]{2}{*}{ Female } & Count & 155 & 154 & 184 & 13 & 506 \\
\hline & & $\begin{array}{l}\% \\
\text { within } \\
\text { gender }\end{array}$ & $30,6 \%$ & $30,4 \%$ & $36,4 \%$ & $2,6 \%$ & $100 \%$ \\
\hline \multirow{2}{*}{\multicolumn{2}{|c|}{ Total }} & Count & 369 & 265 & 311 & 58 & 1003 \\
\hline & & $\begin{array}{l}\% \\
\text { within } \\
\text { gender }\end{array}$ & $36,8 \%$ & $26,4 \%$ & $31 \%$ & $5,8 \%$ & $100 \%$ \\
\hline
\end{tabular}

\begin{tabular}{|l|l|l|l|}
\hline & Value & df & Asymp. sig. (2-sided) \\
\hline & & &
\end{tabular}




\begin{tabular}{|l|l|l|l|} 
Pearson chi-square & $44,436^{\mathrm{a}}$ & 3 & 0,000 \\
\hline Likelihood ratio & 45,590 & 3 & 0,000 \\
\hline Linear-by-linear association & 2,914 & 1 & 0,088 \\
\hline $\mathbf{N}$ of valid cases & 1003 & & \\
\hline & & & \\
\hline $\begin{array}{l}\text { a } 0 \text { cells }(0,0 \%) \\
28,74\end{array}$ & & \\
\hline
\end{tabular}

\begin{tabular}{|c|c|l|l|}
\hline \multicolumn{2}{|c|}{} & \multicolumn{1}{|c|}{ Value } & \multicolumn{1}{c|}{ Approx. Sig. } \\
\hline Nominal by & \multicolumn{1}{|c|}{ Phi } & 0,210 & 0,000 \\
\hline Nominal & Cramer's $\boldsymbol{V}$ & 0,210 & 0,000 \\
\hline N of valid cases & & 1003 & \\
\hline \multicolumn{4}{|l}{$\begin{array}{l}\text { Not assuming the null hypothesis } \\
\text { - Using the asymptotic standard error assuming the null hypothesis }\end{array}$} \\
\hline
\end{tabular}

The effect size measured indicated a small effect, confirming a relative magnitude of difference between males and females. The proportion of males who are not bothered by exposure to unsolicited pornography is much greater than the proportion of females. This shows statistically that males are more tolerant towards pornography, whereas females are more likely to be offended by such content. In Question 14 of the survey, respondents were asked to what extent they thought students should have access to pornography on UJ's computer facilities. Table 5 shows that males indicated a higher occurrence of restricted access and total access opposed to female respondents. Statistical analysis was done to determine the size of the effect.

Table 5 Cross tabulation of gender differences for Question 14 (access to pornography on the UJ computer facilities)

\begin{tabular}{|c|c|c|c|c|c|c|}
\hline & \multicolumn{4}{|c|}{ Access to pornography on UJ computer facilities } \\
\hline & & & No access & $\begin{array}{c}\text { Restricted } \\
\text { access }\end{array}$ & Total access & Total \\
\hline \multirow{4}{*}{ Gender } & \multirow[b]{2}{*}{ Male } & Count & 259 & 186 & 49 & 494 \\
\hline & & $\begin{array}{l}\text { \% } \\
\text { within } \\
\text { gender }\end{array}$ & $52,4 \%$ & $37,7 \%$ & $9,9 \%$ & $100 \%$ \\
\hline & \multirow[b]{2}{*}{ Female } & Count & 347 & 138 & 20 & 505 \\
\hline & & $\begin{array}{l}\text { \% } \\
\text { within } \\
\text { gender }\end{array}$ & $68,7 \%$ & $27,3 \%$ & $4 \%$ & $100 \%$ \\
\hline \multirow{2}{*}{\multicolumn{2}{|c|}{ Total }} & Count & 606 & 324 & 69 & 999 \\
\hline & & $\begin{array}{l}\% \\
\text { within } \\
\text { gender }\end{array}$ & $60.7 \%$ & $32,4 \%$ & $6,9 \%$ & $100 \%$ \\
\hline
\end{tabular}

\begin{tabular}{|l|l|l|l|}
\hline & Value & df & Asymp. sig. (2-sided) \\
\hline & & &
\end{tabular}




\begin{tabular}{|l|l|l|l|} 
Pearson chi-square & $31,96^{\mathrm{a}}$ & 2 & 0,000 \\
\hline Likelihood ratio & 32,416 & 2 & 0,000 \\
\hline Linear-by-linear association & 31,913 & 1 & 0,000 \\
\hline $\mathbf{N}$ of valid cases & 999 & & \\
\hline & & & \\
\hline $\begin{array}{l}\text { a } 0 \text { cells }(0,0 \%) \text { have expected count less than 5. The minimum expected count is } \\
34,12\end{array}$ \\
\hline
\end{tabular}

\begin{tabular}{|l|l|l|l|}
\hline \multicolumn{2}{|c|}{} & \multicolumn{1}{|c|}{ Value } & \multicolumn{1}{c|}{ Approx. sig. } \\
\hline Nominal by & \multicolumn{1}{|c|}{ Phi } & 0,179 & 0,000 \\
\hline Nominal & Cramer's $\boldsymbol{V}$ & 0,179 & 0,000 \\
\hline N of valid cases & & 999 & \\
\hline \multicolumn{3}{|l}{$\begin{array}{l} \\
\text { - Not assuming the null hypothesis } \\
\text { - Using the asymptotic standard error assuming the null hypothesis }\end{array}$} \\
\hline
\end{tabular}

A small effect size was achieved, indicating the relative magnitude of the difference between male and female respondents. The proportion of females who believe no access to pornography should be granted is marginally greater than the proportion of males who believe no access should be granted to pornography. This analysis again shows that females are less inclined to access pornography or encourage access to pornography than their male counterparts.

top

\section{Interpretation of results from questionnaires}

The frequencies from the evaluation of the questionnaires have been converted into figures and tables allowing easier understanding and graphical representation. Biographic information was obtained from Questions 1 to 4. University computer facility usage was dealt with in Questions 5 and 6. Question 7 dealt with the university's AUP. Personal experience with the university's computer facilities was addressed in Questions 8 to 17. The following is a discussion on each of these sections.

\subsection{Biographic information}

Gender distribution was almost even, with a total of 49,4\% male participants and $50,6 \%$ female. Most of the respondents (71,3\%) enrolled during or after 2004. The largest group of students first registered in 2006, which made up 26,7\% of the sample. Respondents completed the questionnaires in the last quarter of the year, giving students who enrolled in 2006 some exposure to the computer and on-line facilities provided by UJ.

In terms of age, the largest grouping of respondents (61,6\%) was between 19 years and 21 years of age. Those between the ages of 17 and 19 years made up 9,6\% and those from 22 to 26 years made up $25,1 \%$ of the students in the sample. Only 3,7\% were 27 years or older (Figure 2).

Figure 2 Results for Question 3: Age of student (in full years) 


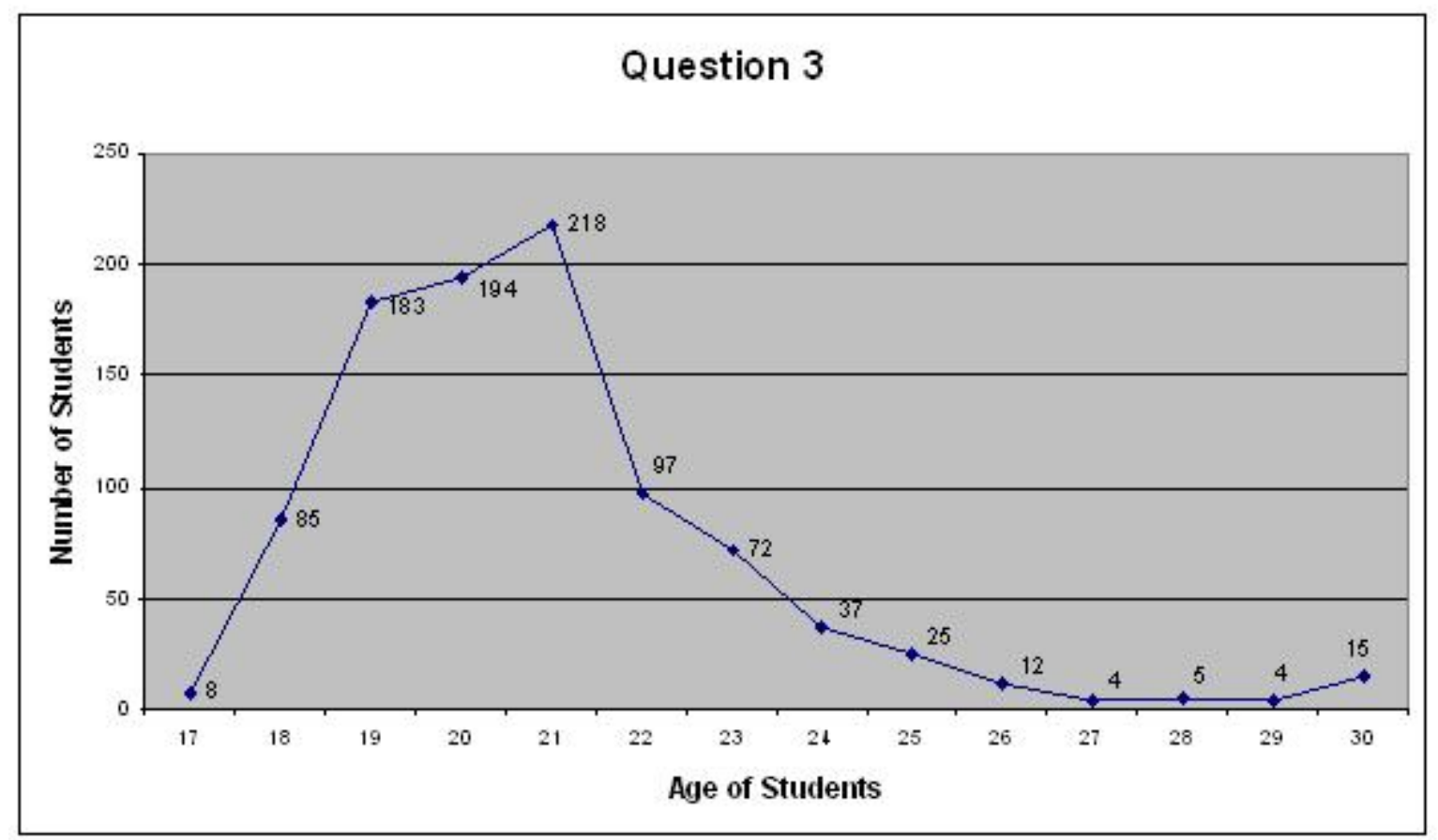

\subsection{University computer facility usage}

With regard to the use of the computer facilities provided by UJ, the sample responded with $42,7 \%$ indicating that they used the computer facilities daily. This illustrated the impact that computers had on the courses they studied, as many departments used computer facilities such as WebCT for the distribution of content as well as for assessment. The next significant grouping of respondents claimed that they used the computer facilities twice a week. Only $4,6 \%$ claimed that they used the computer facilities once a month or less frequently.

For Question 6, respondents were asked to rank their computer facility usage, with 1 being the most important or most frequently used and 5 being the least frequently used. WebCT and Edulink were recorded as the most useful, with 32,5\% ranking this as number 1 . This was followed by surfing the Web at $29 \%$ and the e-mail facility $27,1 \%$. The least used online facility that UJ provided, according to the students who responded, was the library services, which include on-line catalogues and electronic journals. This facility was rated as 5 (least frequently) by $34 \%$ of the students.

\subsection{University AUP}

For Question 7, students were asked if they thought UJ had a policy that governs the use of the computer facilities. Of the respondents, $47,3 \%$ indicated that there was such a policy in place and $11,4 \%$ that such a policy did not exist, $32,0 \%$ were unsure and only $9,4 \%$ indicated that they had seen such a policy.

When the results are broken down into the different campuses (Figure 3), the campus with the highest recorded awareness was the Kingsway campus, where 53,5\% of the students reported that there was such a policy in place and $12 \%$ indicated that they had seen this policy. The campus with the lowest awareness was East Rand, where 31,3\% of the students indicated that there was a policy that governs the use of computer facilities at UJ and only $6,3 \%$ indicating that they had seen the policy.

Figure 3 Results for Question 7 (per campus): Do you think the university has a policy that governs the use of the computer facilities? 


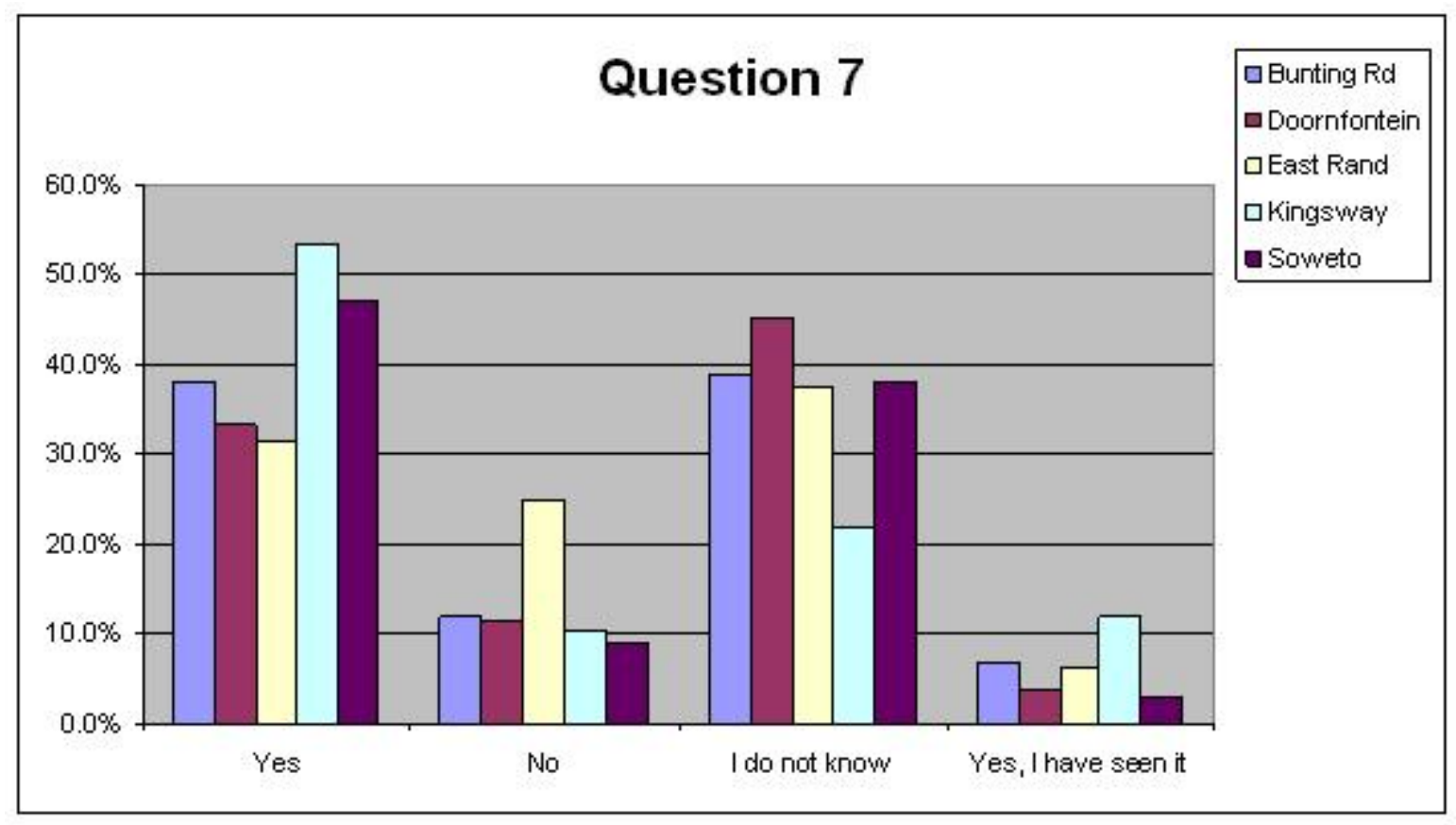

\subsection{Personal experience with the university's computer facilities}

With regard to Question 8, the largest group of respondents (31,6 \%) indicated that they surfed the WWW (Internet) at least once a day, followed by a close 31,3\% who surfed twice a week The majority of respondents had experienced content being blocked at some stage of their university career. Only 18,7\% of the students indicated that they had never had access blocked before. The largest group of respondents who experienced content being blocked was 33,9\%; they had access blocked once or twice, not often.

When looking at the responses for the different campuses, respondents at Bunting Rd (29,7\%) and Doornfontein (41,3\%) indicated that they were often confronted with blocked access. Students at East Rand (31,3\%), Kingsway (19,2\%) and Soweto (14,7\%) stated that they often came across a Web site that had been blocked (Figure 4).

Figure 4 Results for Question 9 (per campus): While surfing the Internet have you ever come across Web sites where access has been blocked? 


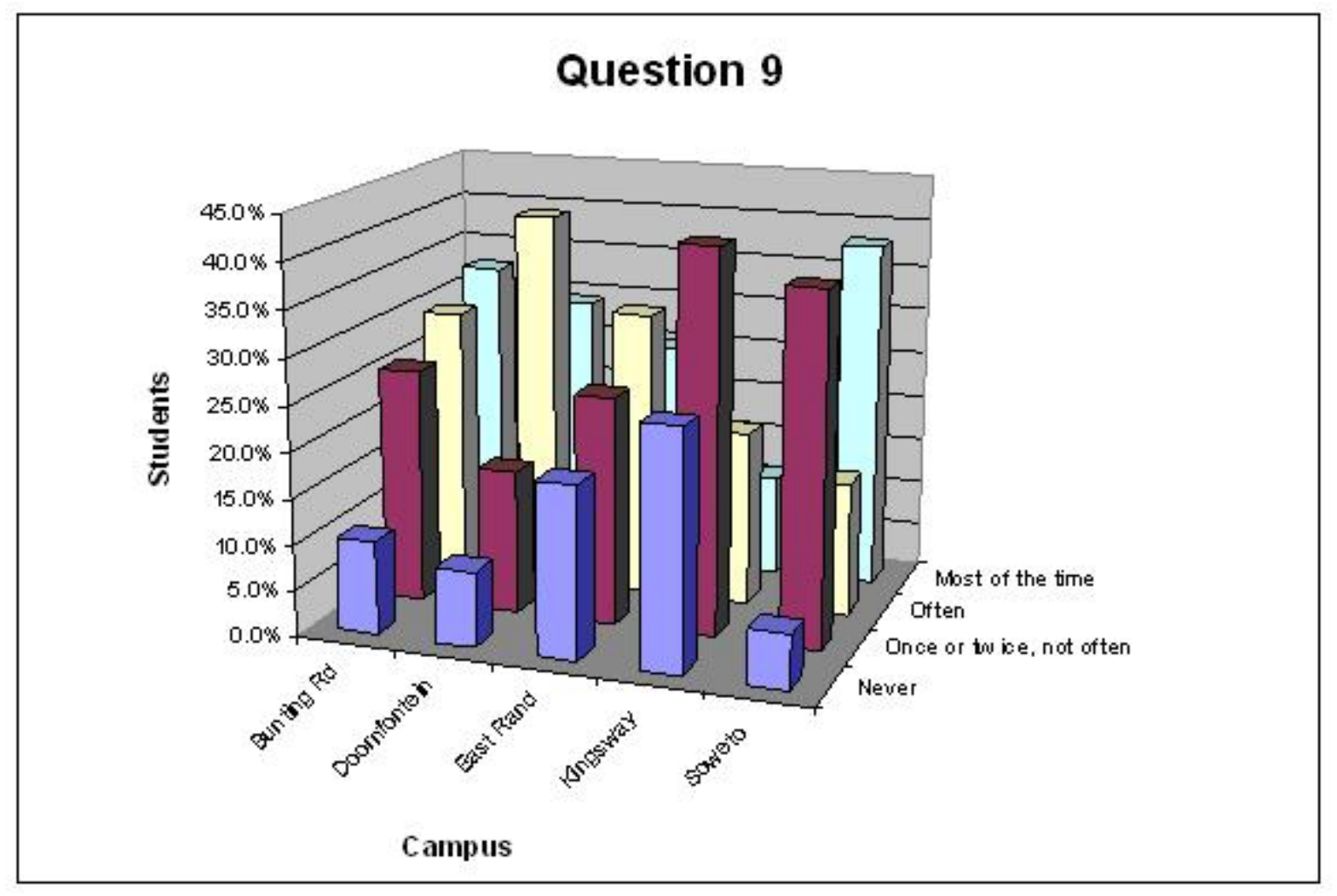

Interesting to note is that when students were asked whether the content the UJ was actively blocking contained academic information (Question 10), 52,1\% indicated 'Yes', with 30,2\% 'No' and $17,7 \%$ being unsure of the nature of the content they were trying to access.

When asked how often the respondents were exposed to unsolicited pornography (Figure 5), $80 \%$ stated never, which indicates that the content filter at UJ is fairly effective at suppressing unwanted content. This was followed by $12,8 \%$ indicating only once or twice and $7,2 \%$ being exposed more than three times.

Figure 5 Results for Question 11: How often have you been exposed to unsolicited pornography while using the on-line computer facilities provided by the UJ? 

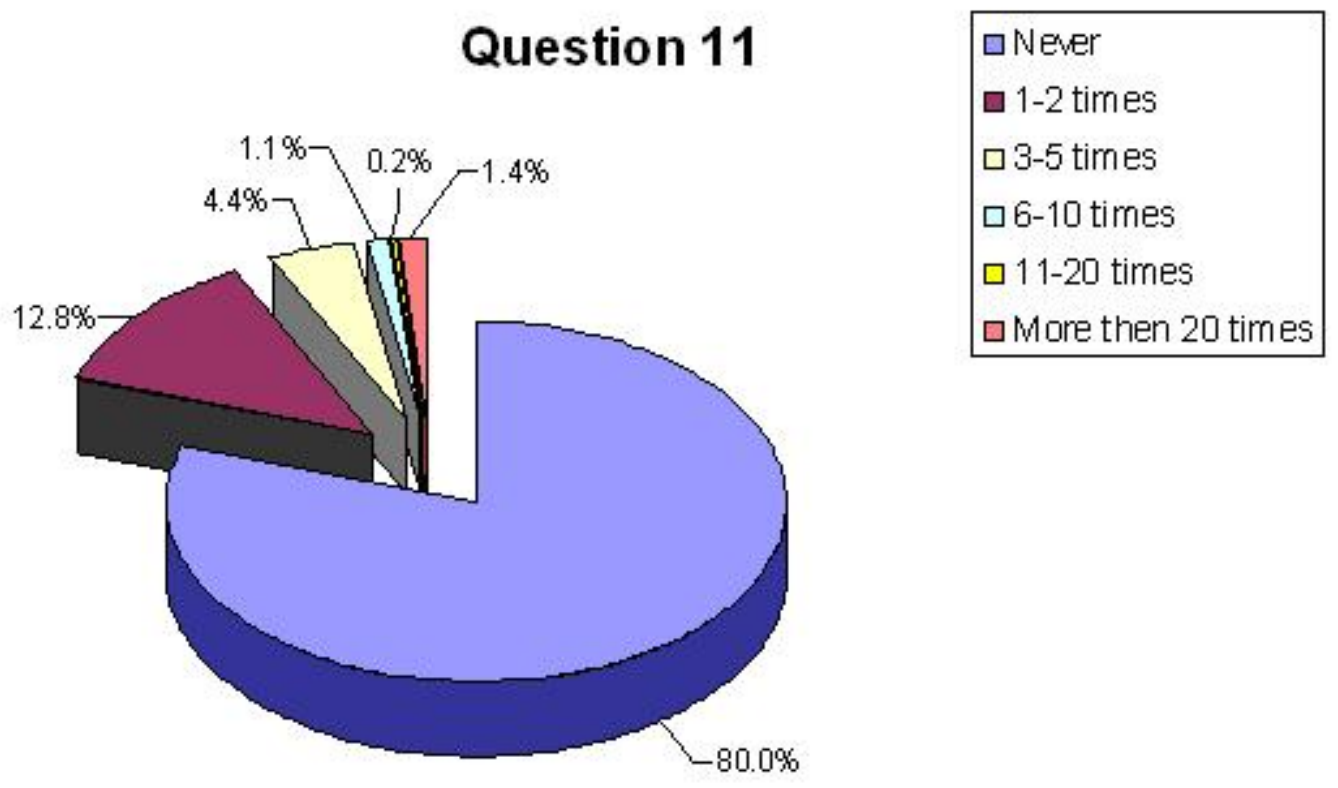

The largest group of 36,7\% indicated that exposure to unsolicited pornography did not bother them, 26,3\% indicated that it did bother them while 31,3\% deemed exposure to be unacceptable. Some (5,7\%) believed they should have the freedom to access pornography (Figure 6).

Figure 6 Results for Question 12: How tolerant are you towards exposure to unsolicited pornography while using the computer facilities provided by the University of Johannesburg?

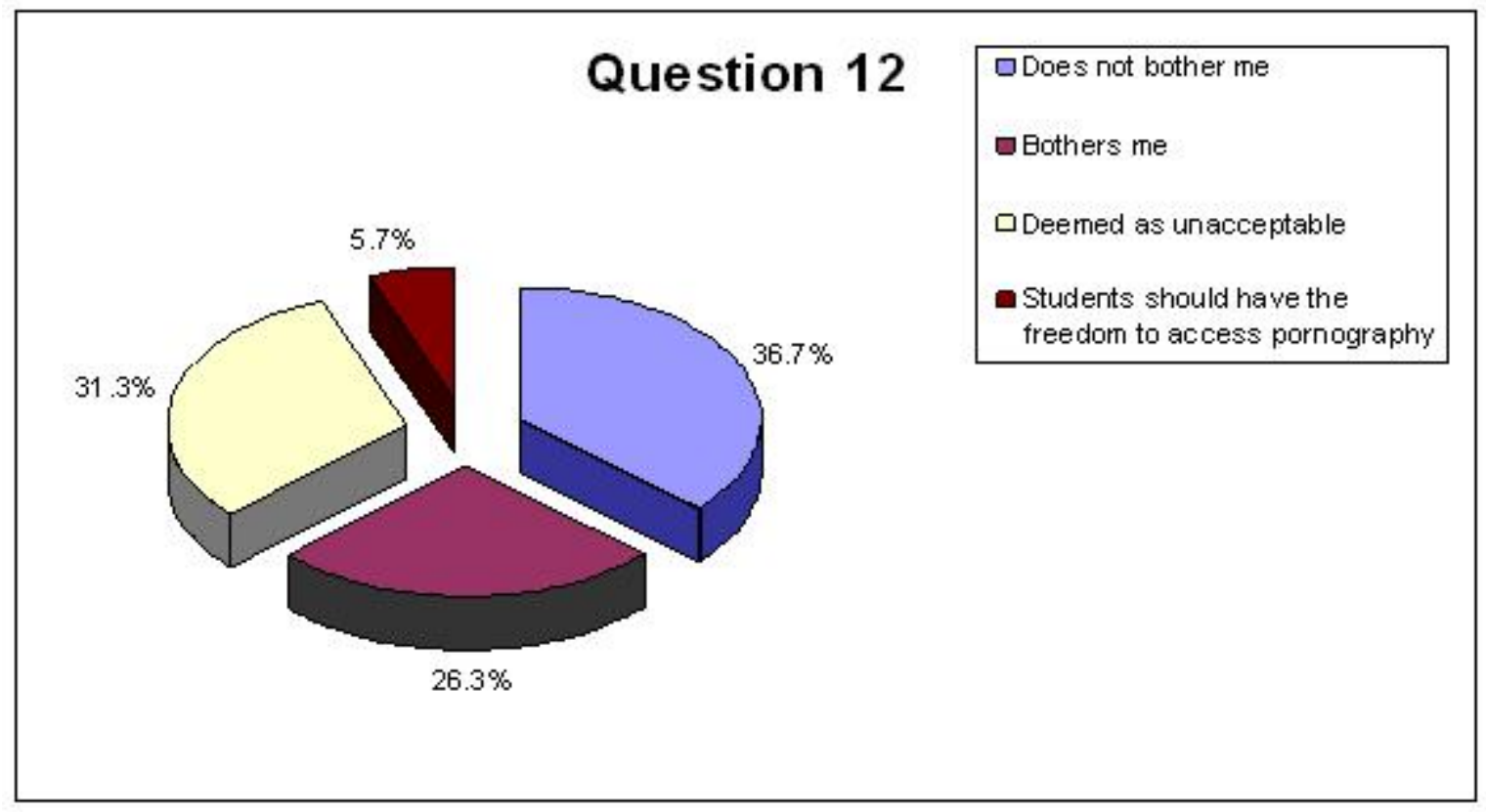

When students were asked if they had ever reported others accessing pornography, 84,5\% indicated 'No', which is not particularly surprising, as $80 \%$ had stated that they had never been exposed to unsolicited pornography at the UJ. Only 8,7\% indicated that they had 
reported such activity, while 6,8\% stated they had thought of it but did not want to make a scene.

When asked to what extent students should have access to pornography, 60,5\% stated 'None' while 32,6\% believed that 'Restricted' access should be granted to those who have permission for research. Surprisingly 6,9\% believed that students should be granted 'Total' access to pornography.

In Question 15 of the survey, students were asked whether or not they should be allowed to access certain types of pornographic content. The content can be classified into three main categories: soft-core, hardcore and obscene (which was sub-divided into child pornography, bestiality and simulated rape or violence for the purpose of this research).

Concerning content labelled soft-core (Figure 7), the response to the question on allowing access to such content was fairly high, with $63,8 \%$ of the respondents indicating that they wanted access to visual erotica, followed by erotic literature with $33,7 \%$, artistic nudity with $26,5 \%$ and child erotica with $19,2 \%$.

Figure 7 Students' views on access to soft-core pornography

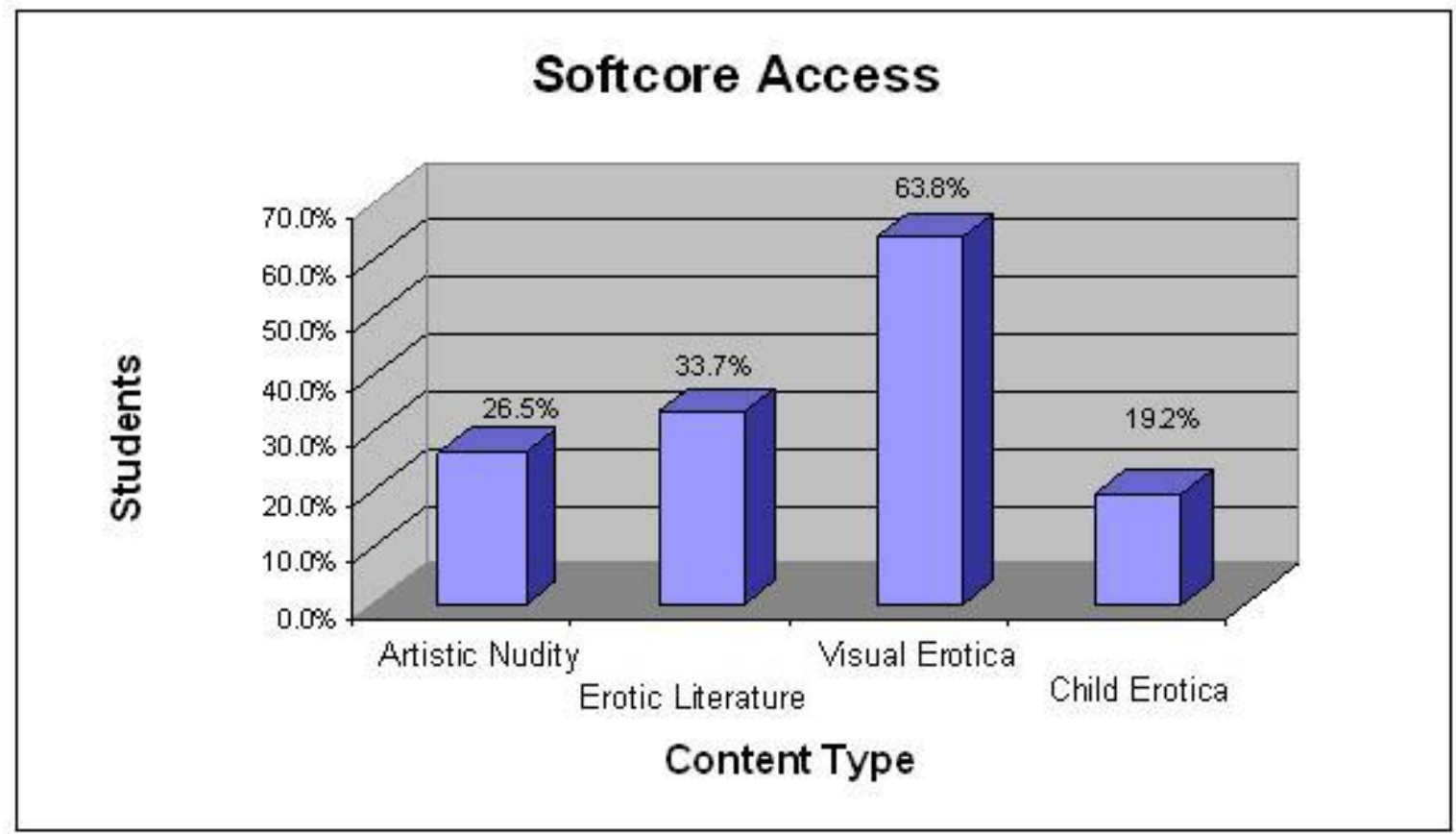

Concerning content labelled hardcore (Figure 8), 17,4\% of the respondents wanted access to full frontal nudity and $14,7 \%$ believed they should have access to acts of sexual penetration. This seems to be relatively high.

Figure 8 Students' views on access to hardcore pornography 


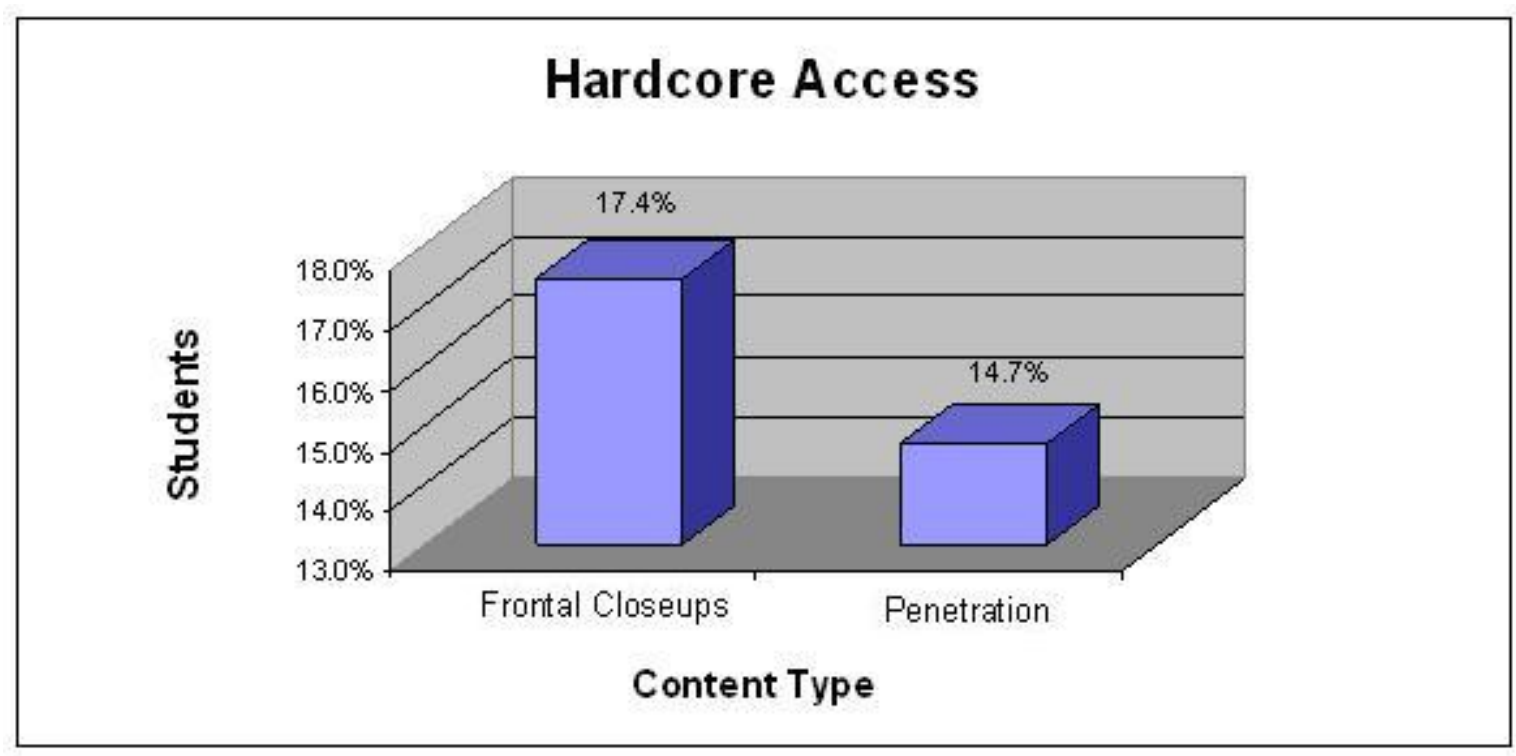

Content labelled obscene (Figure 9), which is illegal to possess and distribute in South Africa, received the following response from the students: $11,0 \%$ of the respondents wanted access to bestiality and 10,8\% believed that they should be allowed to access content containing acts of simulated rape or violence.

Figure 9 Students' views on access to obscene pornography

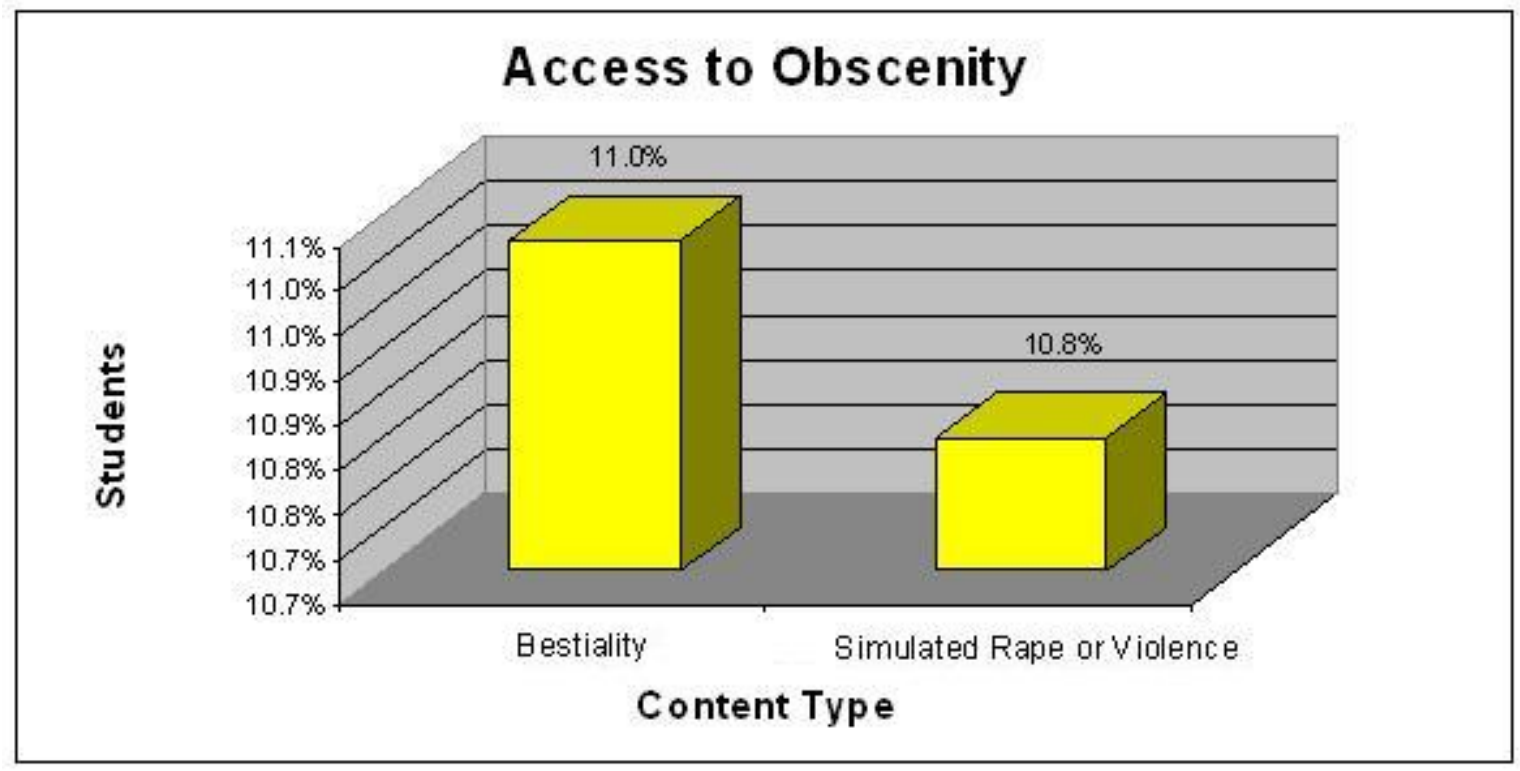

The last category was child pornography, which is also obscene and therefore illegal to access and distribute in South Africa. In this category 23,4\% of the respondents believing they should be allowed to access content of exposed children or pseudo images (Figure 10). The reason for such a high response might be the lack of knowledge on the severe implications of pseudo images, which can include content such as cartoons and comics depicting underage sexual activity. The other category of child pornography includes sex acts involving children, which $13,8 \%$ believe they should be allowed to access.

Figure 10 Students' views on access to child pornography 


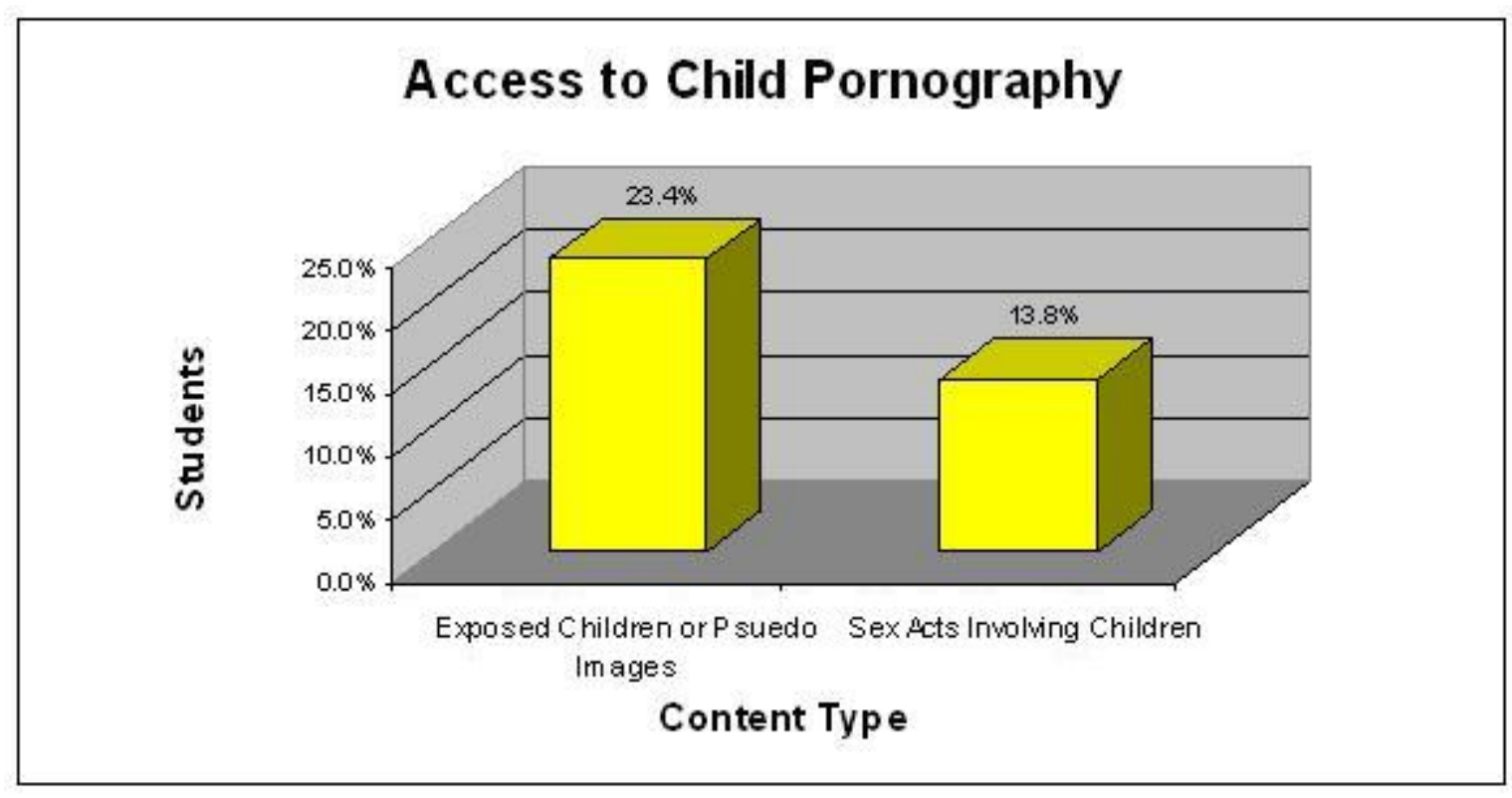

It is interesting to note that, with regard to gender, females consistently responded negatively to access to these various types of pornography. Males, on the other hand, seem to have a more inquisitive nature concerning the issue of pornography. Multiple studies have indicated that men, especially adolescents, are greater consumers of pornography (HaggerstormNordin, Hanson and Tyden 2005; Hald 2006). Figure 11 illustrates the difference between male and female students' opinion on what they should have access to.

Figure 11 Results for Question 15 (per gender): Please indicate whether or not you think students should have access to the following content. 


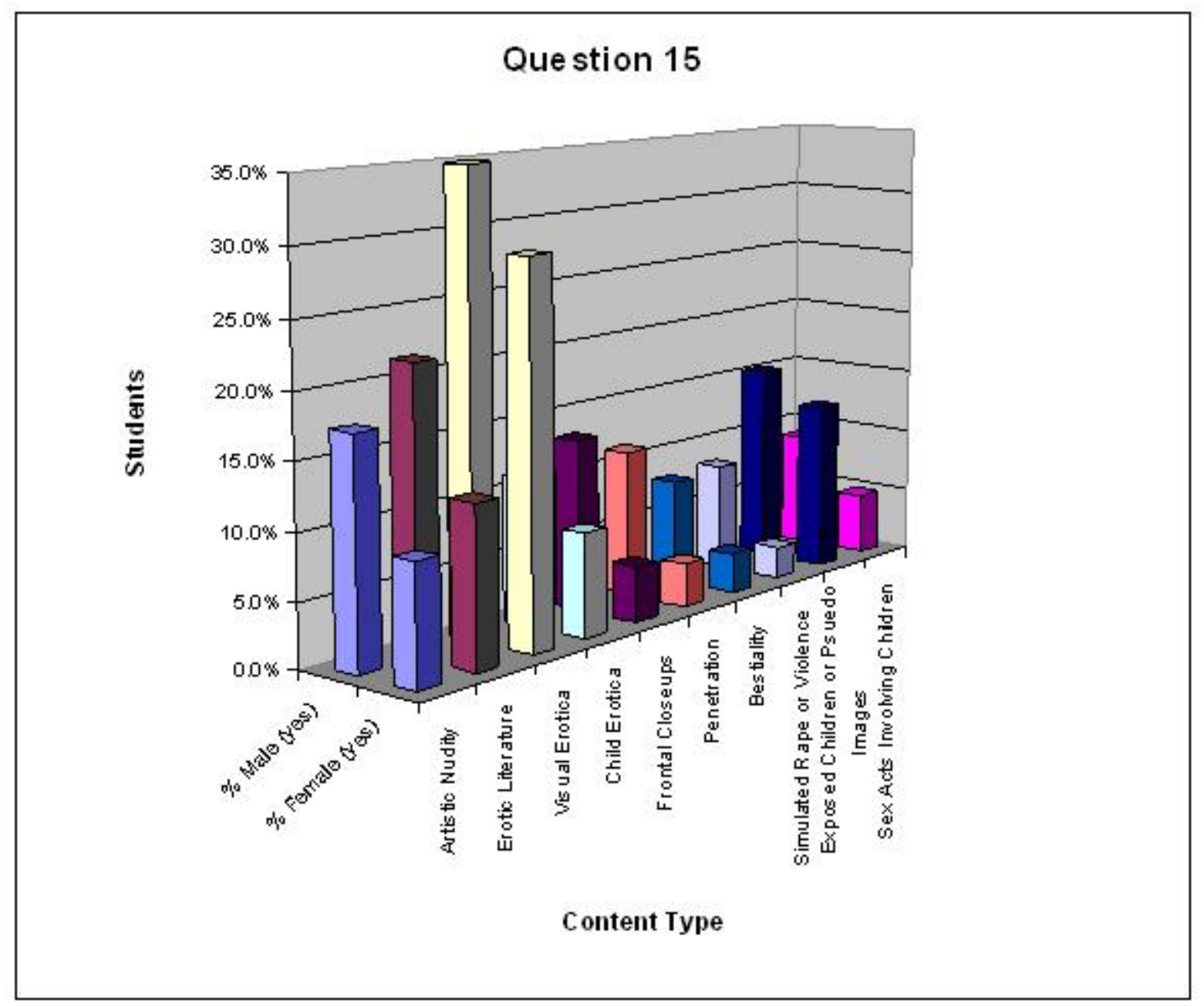

Question 17 was an optional question at the end of the survey, which only 3,2\% did not answer. Students were asked how often they used the computer facilities at UJ to access pornography. The majority indicated 'Never' followed by 5,7\% claiming once or twice. A notably small 2,2\% stated that they used UJ computer facilities daily to access pornography (Figure 12).

Figure 12 Results for Question 17: How often have you used the computer facilities provided by the university to access pornography? 


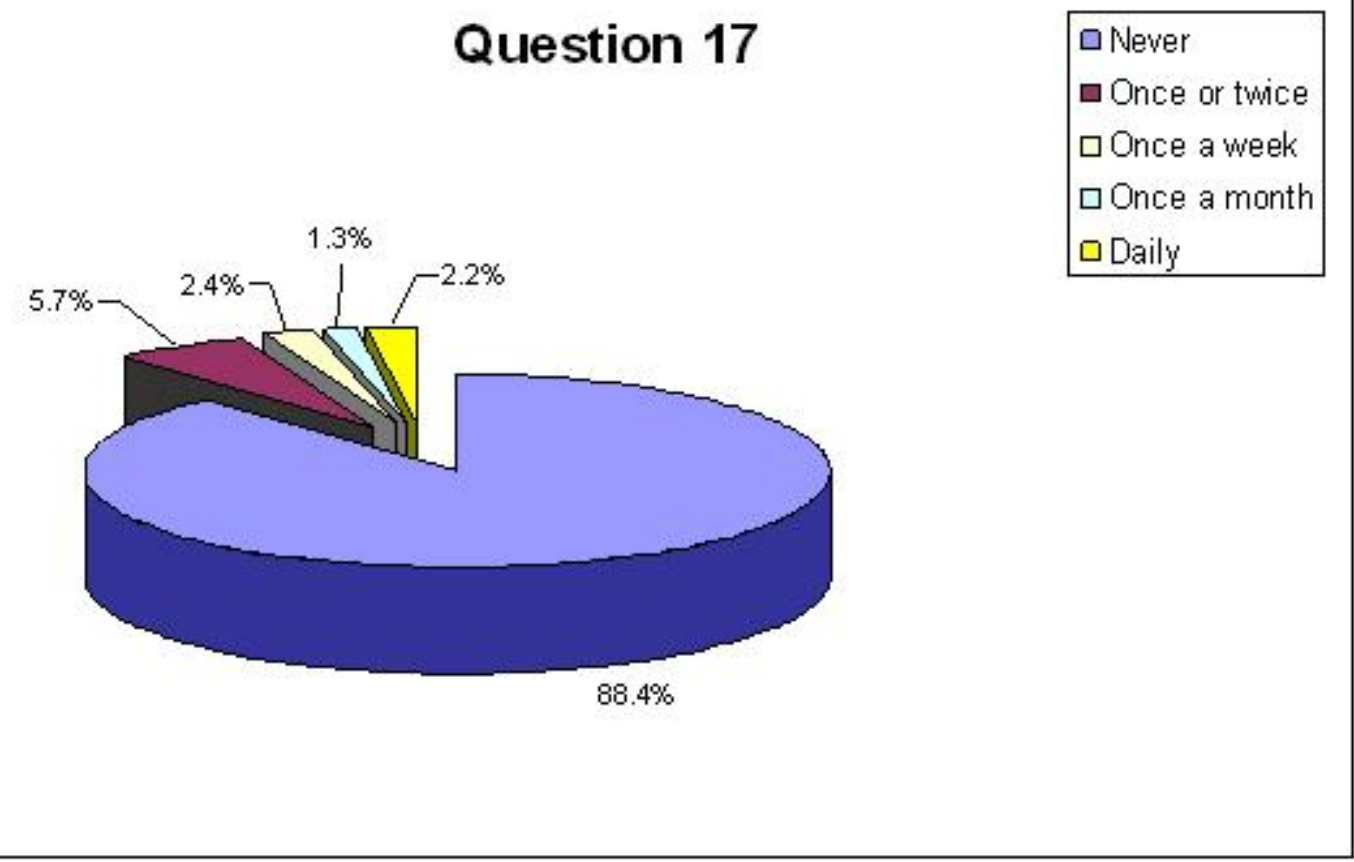

top

\section{Conclusion}

The findings from the research are significant in that it gives the UJ informative input into the effectiveness of current content filtering solutions and acceptable use policies at the various campuses and insight into the content to which students believe they should have access to. Since the UJ is a fairly new institution, it is recommended that the existing policies and content filtering solutions be integrated to accommodate all campuses to ensure standardization.

\section{References}

Chheuy, R. 2004. You're studying what?!: a look at the colourful courses offerings of modern academia. [Online]. Available WWW: http://www.calpatriot.org/article.php? articleID=148. (Accessed 29 May 2007).

Concise Oxford English Dictionary. 2004. Oxford: Oxford University Press.

Cullen, L. 2006. Time Magazine: sex in syllabus. [Online]. Available WWW: http://www.time.com/time/magazine/article/0,9171,117697-3,00.html. (Accessed 24 April 2007).

Haggerstorm-Nordin, E., Hanson, U. and Tyden, T. 2005. Association between pornography consumption and sexual practices among adolescents in Sweden. International Journal of STD \& AIDS 16(2):102-107.

Halavais, A.C. 2005. Small pornographies. SIGGROUP Bulletin 25 (2):19-22.

Hald, G.M. 2006. Gender differences in pornography consumption among young heterosexual Danish adults. Archives of Sexual Behaviour 35(5):557-585. 
Laughton, P. and Rensleigh, C. 2007. Exposure to online pornography at the University of Johannesburg: second phase empirical results. International Journal of Technology, Knowledge and Society 3(4): 37-44.

Merrian Webster Dictionary of Law: definition of pornography. 1996. [Online]. Available WWW: http://dictionary.reference.com/search?q=pornography. (Accessed 29 May 2007).

Rosenthal, R., Rosnow, R. and Rubin, D. 2000. Contrasts and effect sizes in behavioural research: a correlational approach. Cambridge: Cambridge University Press.

Rothery, B. 2003. Guide to child pornography on the Internet. [Online]. Available WWW: http://www.inquisition21.com/articles view 7 page_num 6.html. (Accessed 29 May 2007).

Watney, M. 2005. Regulation of the Internet pornography in South Africa. In: Proceedings of the 7th WWW Conference on WWW Applications, September 2005. Cape Town. [Online]. Available WWW: http://www.zaw3.co.za. (Accessed 29 May 2007).

Wikipedia. 2005. Erotica. [Online]. Available WWW:

http://www.wikipedia.org/wiki/Erotica. (Accessed 29 May 2007).

ISSN 1560-683X

Published by InterWord Communications for Department of Information and Knowledge Management, University of Johannesburg 